\title{
ISOLASI DAN IDENTIFIKASI BAKTERI PENGHASIL PROTEASE YANG DISKRINING DARI TERASI
}

\author{
NOVI ARFARITA \\ Faculty of Agriculture, University of Islam Malang-UNISMA \\ Email: arfarita@yahoo.com
}

\begin{abstract}
Terasi is a traditional fermented shrimp paste of Indonesia popularly used as an important ingredient in many Indonesian cuisines, and further screened for their protease-producing bacteria. A total of 117 bacterial isolates were retrieved from 4 terasi samples. When inoculatedusing skim milk agar, 71 isolates ( 61\%) produced distinct clear zones implying their proteolytic activity. A bacterial isolate namely Bacillus S2-3 wasselected for further study due to its widest clear zones when thebacterial cells and culture supernatant were used. This strain could grow up to $60^{\circ} \mathrm{C}$ with a broad $\mathrm{pH}$ range of $5-9$. The optimal growth condition was at $\mathrm{pH} 6$ and $37^{\circ} \mathrm{C}$. The enzyme activity was also characterized using azocasein method. The optimal pH of bacterialenzymes was between 6 and 7 whereas the optimal temperature of Bacillus $S 2-3$ proteases was $22-24^{\circ} C$. For thermostability, the S2-3 enzymes remained active up to $2 \mathrm{~h}$ at 40 and $50^{\circ} \mathrm{C}$. The results ofbiochemical tests, BacillusS2-3 was identified as Bacillussubtilis, later explored it is potential for the purposes for food industry.

Key word : Terasi, Identified, Bacteri, Protease
\end{abstract}

\section{PENDAHULUAN}

Protease terjadi secara alami padasemua organisme. Enzim ini terlibat dalam banyak fungsi dari tingkat sel sampai ke tingkat organ dan organisme, dari pencernaan sederhana protein makanan sampai proses metabolisme yang melibatkan pengaturan tingkat tinggi. Protease terdapat pada seluruh organisme untuk dipergunakan diberbagai proses metabolisme dan juga menentukan masa protein lain yang berperan pada proses fisiologis penting seperti hormon, antibodi, atau enzim lainnya. Secara umum, protease ekstra seluler mengkatalisis hidrolisis protein besar menjadi molekul yang lebih kecil untuk penyerapan berikutnya oleh sel sedangkan protease intraselular memainkan peran penting dalam regulasi metabolisme (Rao et. al., 1998).

Protease adalah salah satu grup enzim paling penting dibidang industri. Sebagian besar protease digunakan dalam deterjen. Penggunaan protease sebagai alternatif bahan kimia telah terbukti berhasil dalam meningkatkan kualitas kulit dan mengurangi pencemaran lingkungan diindustri kulit. Salah satu kegunaan utama protease adalah dalam industri makanan. Protease digunakan untuk melunakkan protein daging, terutama kolagenase. Protease lain yang banyak digunakan adalah rennin, yang memecah protein susu dan menyebabkan mereka mengental, membentuk dasar keju. Protease juga digunakan untuk untuk menjernihkan bir dan untuk memperbaiki tekstur adonan dalam pembuatan roti(emulsifier). Selain itu, enzim proteolitik telah digunakan untuk waktu yang lama dalam berbagai bentuk terapi. Penggunaannya dalam aplikasi biomedis yang penting didasarkan pada beberapa studi klinis telah menunjukkan manfaat dalam onkologi, kondisi peradangan, kontrol reologi darah, dan regulasi kekebalan tubuh (Bains, 1998).

Sebuah kenyataan protease secara fisiologis diperlukan oleh organisme untuk hidup, sehingga tentunya protease bisa ditemukan di mana-mana, seperti tanaman, hewan dan mikroorganisme. Mikroorganisme merupakan sumber enzim yang sangat baik karena keragaman biokimia yang luas dan ketahanan enzim mikroorganisme untuk manipulasi genetik. Produksi protease dari mikroba berjumlah sekitar $40 \%$ dari total penjualan enzim di seluruh dunia (Godfrey \& Barat, 1996; Walsh, 2002). Protease dari sumber mikroba lebih disukai di sektor industri dari pada enzim dari sumber tanaman dan hewan karena enzim dari mikroba memiliki hampir semua karakteristik yang diinginkan untuk aplikasi bioteknologi. Kebanyakan protease komersial diproduksi dari bakteri, terutama yang bersifat netral dan basa. Bakteribakteri tersebut termasuk ke dalam genus 
Bacillus diantaranya B.macerans, B.licheniformis, dan B.subtilis. Bakteri Bacillus adalah produsen yang baik untuk menghasilkan protease ekstra seluler karena ketahanan mereka pada suhu tinggi dan rentang $\mathrm{pH}$ yang luas (Olajuyigbe \& Ajele, 2005; Nagata \& Matsumura, 1986).

Terasi merupakan salah satu produk fermentasi khas Indonesia yang dilakukan dengan penggaraman dan bahan dasar yang terbuat dari udang dan atau ikan berupa pasta padat kering. Terasi berfungsi sebagai bumbu karena adanya asam glutamat dan rasa spesifik (Surono \& Hosono, 1994). Terasi, biasanya biasanya dalam bentuk batangan berwarna gelap. Warna dan aroma terasi bervariasi tergantung pada masing-masing desa memproduksinya. Rentang warna dari warna ungu kemerahan-lembut sampai coklat gelap. Terasi memiliki aroma tajam, sehingga sebelum ditambahkan ke bumbu makanan, sering dipanggang di atas api. Aroma tajam dikurangi dengan metode memasak atau memanggang (Suprapti,2002).

Akan tetapi infomasi tentang mikroba atau mikroorganisme yang terlibat dalam proses fermentasi terasi, terutama bakteri penghasil proteasen yang sangat terbatas. Dalam studi ini, kami bertujuanuntuk mengisolasi dan mengidentifikasi strain bakteri yang mampu menghasilkan protease dari beberapa sampel terasi. Selain itu, beberapa karakteristik mendasar dari strain bakteri potensial juga diobservasi.

\section{BAHAN DAN METODE}

\section{Isolasi dan Identifikasi Bakteri}

Sampelterasi dikumpulkan daritiga wilayahdi PulauJawa yaitu di daerah Cirebon, Tuban dan Malang, kemudian digunakan untuk mengisolasi bakteri penghasil protease. Dalam tahap ini, digunakan 10 gram terasi yang ditambahkan ke dalam $90 \mathrm{ml}$ larutan pepton $0,1 \%$ steril dan dihomogenkan dalam sebuah stomacher. Larutan dengan tingkat pengenceran yang sesuai kemudian diambil $10 \quad \mu l$ dan dilakukan metode spread plate agar pada media kaseinagar, diinkubasi pada $357^{\circ} \mathrm{C}$ selama 24 jam. Koloni yang menunjukkan zona bening kemudian dipilih dan streak ulang sampai didapatkan kultur murni. Satu strain terbaik yang ditandai dengan zona bening yang jelas serta mempunyai diameter tertinggi kemudian diamati sifat morfologi dan fisiologisnya, yaitu termasuk bentuk sel dengan pewarnaan Gram, dan kondisi pertumbuhan (aerobik atauanaerobik). Uji biokimia menggunakan API50Chkit (bioMerieux, Inc).

\section{Optimalisasi Kondisi Pertumbuhan Bakteri}

Sebanyak $0.2 \mathrm{ml}$ kultur cair bakteri ditransferke dalam $100 \mathrm{ml}$ media NB (NutientBroth) yang mengandung $0,1 \%$ kasein dan kemudian diinkubasi pada $37^{\circ} \mathrm{C}$ dengan dishaker pada $150 \mathrm{rpm}$ selama 3 hari. Pertumbuhan bakteri diamati setiap 12 jam dengan mengukur OD pada $600 \mathrm{~nm}$.

\section{Aktivitas Proteolitik}

Untuk menguji aktivitas proteolitik, sebanyak $15 \mu \mathrm{l}$ cairan supernatan yang mengandung enzim diteteskan pada piringan kertas steril dan diinkubasikan pada cawan petri berisi SMA (Skim Milk Agar). Cawan petri kemudian diinkubasi pada $37^{\circ} \mathrm{C}$ selama 12 jam. Aktivitas enzim proteolitik diamati dengan mengukur zona bening. Kondisi pertumbuhan bakteri juga diamati dalam kisaranp H5 - 9 dan pada suhu yang bervariasi antara $22-60^{\circ} \mathrm{C}$.

\section{HASIL DAN PEMBAHASAN}

Dengan menggunakan susu skim agar, koloni yang mampu menghasilkan zona bening yang jelas diisolasi secara acakdan kemudian dimurnikan dengan di streak pada cawan petri yang bersisi NA (Nutrient Agar). Dari 117 isolat bakteri yang diisolasi, 71 isolat mampu menghasilkan zona bening yang jelas (Tabel 1). Aktivitas proteolitik mereka selanjutnya diuji menggunakan teknik inkubasi spot. Satu isolat yaitu S2-3 menunjukkan aktivitas tertinggi kemudian dipilih untuk digunakan lebih lanjut dalam penelitian ini. 
Tabel 1.Distribusi isolat bakteri yang didapatkan dari empat sampel bakteri.

\begin{tabular}{clcc}
\hline Sampel & Lokasi & $\begin{array}{c}\text { Total strain yang } \\
\text { didapatkan }\end{array}$ & $\begin{array}{c}\text { Jumlah bakteri } \\
\text { penghasil protease } \\
(\boldsymbol{\%})\end{array}$ \\
\hline $\mathbf{1}$ & Branded (Mamasuka), Jawa Barat & 26 & $15(58)$ \\
\hline $\mathbf{2}$ & Cirebon - Jawa Barat & 32 & $19(59)$ \\
\hline $\mathbf{3}$ & CookingTrasi - Malang- Jawa Timur & 24 & $12(50)$ \\
\hline $\mathbf{4}$ & Tuban - Jawa Timur & 35 & $25(71)$ \\
\hline & Total & 117 & $71(69 \%)$ \\
\hline
\end{tabular}

Strain bakteri ini adalah Gram positif (Gambar 1.a) dan mampu tumbuh di bawah kondisi anaerob. Berdasarkan API profil biokimia dengan menggunakan beberapa uji biokimia dan menggunakan API kit diketahui bahwa bakteri S2-3 diklasifikasikan sebagai Bacillussubtilis.

Hubungan antara pertumbuhan strain S2-3 dan produksi protease ditentukan dan diamati pada kultur cair (NB) dan dipantau setiap 12 jam dengan mengukur OD pada $600 \mathrm{~nm}$ serta adanya zona beningcawan petri yang merisi susu skim agar. Hasil penelitian menunjukkan bahwa produksi protease bergantung pada pertumbuhan bakteri. Strainbakteri ini dapat tumbuh hingga $60^{\circ} \mathrm{C}$ dengan kisaran $\mathrm{pH}$ yang luas yaitu dari $5-9$. $\mathrm{pH}$ optimal bagi pertumbuhan isolat $\mathrm{S} 2-3$ adalah 6 sedangkan suhu optimum adalah suhu $\operatorname{kamar}\left(22-30^{\circ} \mathrm{C}\right)($ Gambar 2).

Pengaruh berbagai suhu pada aktivitas proteolitik dari Bacillus subtilis S2-3 diamati dengan mengukur diameter zona bening $\left(\mathrm{cm}^{2}\right)$ dan dimonitor setiap 12 jam (Gambar 3.b). Suhu optimum untuk aktivitas proteolitik Bacillus subtilisS2-3 adalah pada suhu kamar dan aktivitas proteolitik terendah pada suhu $60^{\circ} \mathrm{C}$. Kegiatan proteolitik pada temperatur yang berbeda juga cenderung mengikuti pertumbuhan sel (Bandingkan Gambar 2 dan 3). Namun, kegiatan proteolitik awal $(0 \mathrm{~h})$ adalah yang tertinggi. Gambar 3 menunjukkan bahwa diameter zona beningBacillus subtilisS2-3 dipantau pada $0 \mathrm{~h}$ (jam ke-0) adalah yang tertinggi. Mungkin, itu disebabkan oleh waktu inkubasisupernatan pada piringan kertas. Padahal, waktu inkubasi untuk pengamatan lain adalah 12 jam.yang kemungkinan dalam kurun waktu 12 jam tersebut terjadi dinamika aktivitas proteolitik yang tidak teramati.

Pengaruh berbagai $\mathrm{pH}$ pada aktivitas proteolitik dari Bacillus subtilis S2-3 diamati dengan mengukur diameter zona bening dan dimonitor setiap 12 jam (Gambar 3.a). PH optimum aktivitas proteolitik untuk bakteri ini adalah 6. Aktivitas proteolitik pada $\mathrm{pH} \mathrm{7,8}$ dan 9 tidak jauh berbeda. Kegiatan proteolitik terendah adalah pada $\mathrm{pH}$ 5. Dengan pengamatan pertumbuhan sel pada berbagai $\mathrm{pH}$, kegiatan proteolitik yang cenderung mengikuti pertumbuhan sel (lihat Gambar 2 dan 3). Tingkat pertumbuhan Bacillus subtilisstrain S23 adalah sejajar dengan aktivitas proteolitik.

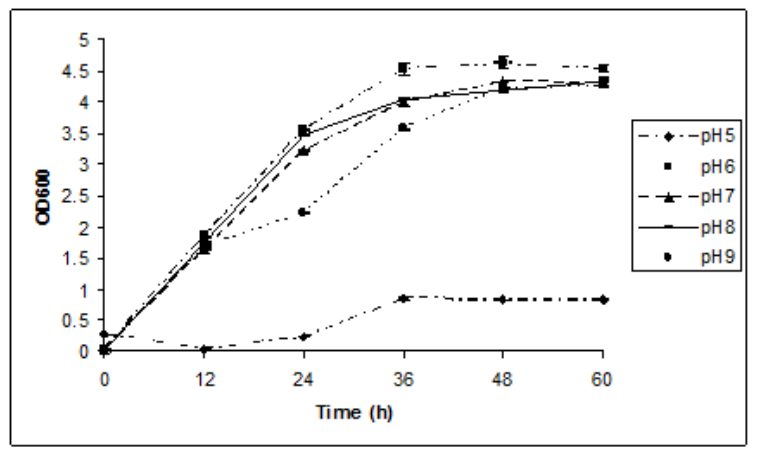

(a)

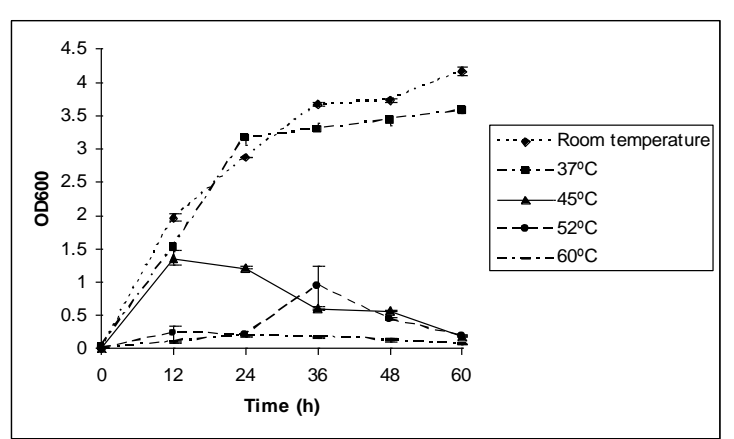

(b)

Gambar 2. (a) Pertumbuhan selBacillus subtilisstrain S2-3 pada kisaran pH 5-9 (diinkubasipada suhu $37^{\circ} \mathrm{C}$ ) dandiukurpadaOD 600 selama 60 jam (h)pada media kultur cair (NB). (b) Pertumbuhan sel Bacillus subtilisstrain S2-3 pada kisaran suhu20-60 ${ }^{\circ} \mathrm{C}$ ( $\left.\mathrm{pH} 6\right)$ dan diukur pada padaOD 600 selama 60 jam (h) pada media kultur cair (NB). 


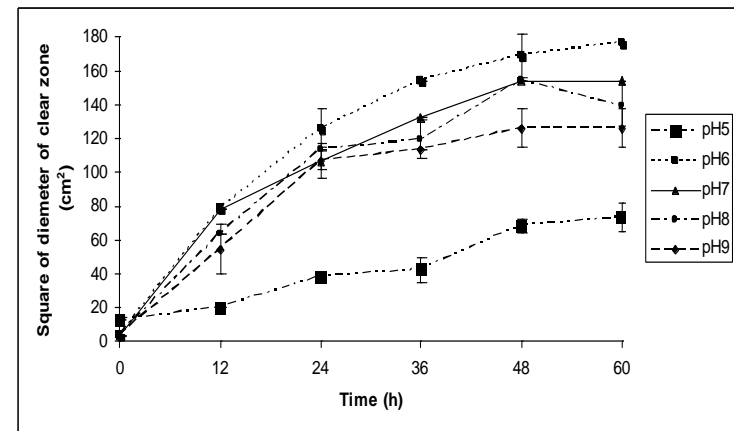

(a)

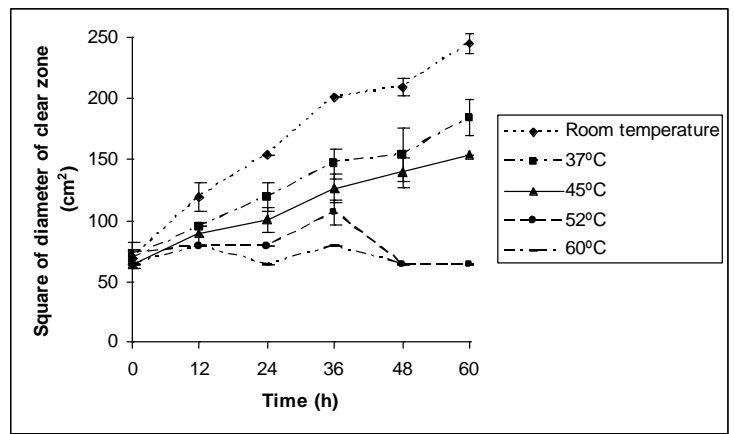

(b)

Gambar 3. Aktivitas proteolitik supernatanBacillus subtilis $\mathrm{S} 2-3$ (dalam $\left.\mathrm{cm}^{2}\right)$ pada kisaran $\mathrm{pH} 5-9$ diinkubasi pada $37^{\circ} \mathrm{C}$ (a) dan pada kisaran suhu $20-60^{\circ} \mathrm{C}(\mathrm{pH}$ 6) (b) yang diamati setiap 12 jam pada cawan petri yang bersisi Agar Kasein.

Terasi telah lama digunakan sebagai bumbu dalam banyak masakan Indonesia. Saat ini, berbagai bentuk terasi telah diproduksi meskipun dengan cara tradisional, yaitu oleh keluarga nelayan lokal di desa-desa pesisir. Oleh karena itu, kemungkinan bahwa kualitas terasi tidak konsisten karena mikroba memfermentasi secara alami dan proses produksi dilakukan secara konvensional. Dalam produksi terasi, akan menjadi penting untuk karakterisasi mikroba konsorsium yang terkandung di dalamnya serta mengoptimalkan proses produksi dan keseragaman kualitasnya. Ini akan membantu dalam pengembangan produk agar kualitas produk dapat dikendalikan dan ditingkatkan. Dengan penekanan pada mikroba fermentasi alami, ini mungkin merupakan sumber baru dan potensi beberapa metabolit yang berguna seperti enzim yang dapat digunakan dalam industri bioteknologi. Dalam penelitian ini, penemuan Bacillus subtilisdalam terasi menunjukkan aktivitas proteolitik yang tinggi sekarang. Isolatbakteri ini diharapkan untuk digunakan sebagai kultur starter murni dalam pembuatan industri makanan misalnya keju.

\section{DAFTAR PUSTAKA}

Bains, W. (1998) Biotechnology from A to Z $\left(2^{\text {nd }}\right.$ edition). Oxford University Press, pp. 146-314.

Chantawannakul, P., Oncharoen, A., Klanbut, K., Chukeatirote, E. danLumyong, S. (2002

Characterization of proteases of Bacillus subtilis strain 38 isolated from traditionally fermented soybean in
Northen Thailand. ScienceAsia 28: 241-245.

Godfrey, T. dan West, S. ( 1996) Industryal enzymology, second edition. Macmillan Publishers Inc. New York. p.3.

Nagata, M. dan Matsumura, T. (1986) Action of the bacterial neutral protease, dispase on cultured cells and its application to fluid suspension culture with a review on biomedical application of this protease. The Japanese Journal of Experimental Medicine 56, 297-307.

Olajuyigbe, F.M. danOjele, J.O. (2005) Production dynamics of extracellular protease from Bacillus species. African Journal of Biotechnology 4, 776-779.

Rao, M.B., Tanksale, A.P., Ghatge, M.S. dan Deshpande, V.V. (1998) Molecular and biotechnological aspects of microbial proteases. Microbiol. Mol. Biol. Rev. 62: 597-635.

Suprapti, L. (2002) MembuatTerasi. Kanisius Yogyakarta, Indonesia. p. 28-40.

Surono, I.S. danHoson, A. (1994) Microflora and their enzyme profile in "Terasi" starter. Bioscience, Biotechnology, and Biochemistry 58, 1167-1169.

Walsh, G. (2002) Proteins: Biotechnology and biochemistry. John Wiley and Sons. p.425. 